\title{
WOMEN IN CONTEMPORARY ENGLISH DRAMA TRANSLATION: ENHANCEMENT AND DOWNPLAY MECHANISMS TO PORTRAY GOLDEN AGE DAMAS
}

\author{
Jorge Braga Riera \\ Universidad Complutense de Madrid
}

\begin{abstract}
In the last two decades British and American drama translators have shown a growing interest in the Spanish classics, resulting in English versions exclusively intended for the stage. Within this particular context, this paper is intended to provide a general view on how a motif present in the source texts, i.e. the role of women, is transferred into the target plays. A close analysis of the translated works reveals how women's acts can be enhanced or downplayed in order to accommodate them to the recipient culture. Hence, political correctness, reaction to male domination, moral squeamishness and honour emerge as important elements to be taken into account. Conclusions will ultimately provide us with information about the current vision of Spanish Golden Age drama through English translation, and will hopefully invite discussion on the validity of these mechanisms to guarantee its reception in the Anglo-Saxon theatre world.
\end{abstract}

\section{Resumen}

El creciente interés que, en las dos últimas décadas, han suscitado los clásicos españoles en los traductores dramáticos británicos y estadounidenses ha impulsado la aparición de versiones en lengua inglesa pensadas exclusivamente para su puesta en escena. Dentro de este contexto, el presente artículo pretende analizar el tratamiento de uno de los motivos más recurrentes en los textos fuente: el papel de la mujer. El estudio de las traducciones muestra cómo el rol femenino puede ser potenciado o minimizado para ajustarlo a la cultura de llegada. Así, son dignos de análisis la corrección política, la reacción ante el poder masculino, los escrúpulos morales o el honor. Las conclusiones extraídas pretenden arrojar información sobre el enfoque actual que, del teatro áureo español, reflejan los textos meta, así como abrir el debate sobre la validez 
de los mecanismos empleados por estos traductores para garantizar la buena acogida de las piezas originales en la dramaturgia anglosajona.

Keywords: Drama translation studies. Woman. Sexuality. Enhancement. Downplay.

Palabras clave: Estudios de traducción dramática. Mujer. Sexualidad. Potenciación. Minimización. 


\section{Introduction}

Over the last years, hundreds of publications have focused on the authors of the Spanish Siglo de Oro, and many playwrights of the period are the subject of theses, dissertations, papers, books and articles published outside Spain. This renewed attention has also boosted the appearance of an increasing number of Spanish classical plays in English translation which are no longer reader-oriented, but intended for the stage (cf. Ruano de la Haza 2005). ${ }^{1} \mathrm{Nev}-$ ertheless, and despite this emerging interest, the comedia is even today a rara avis in the Anglo-Saxon world, and performances outside academic circles (symposiums, conferences, festivals, university departments, etc.) are still quite uncommon. ${ }^{2}$ Many scholars and practitioners have precisely pointed out the scarce presence of Spanish classics in English language, which is in part a direct consequence of the problems inherent to the rendering of this sort of texts (see Zatlin 2005, Boyle \& Johnston [eds.] 2007 or Paun de García $\&$ Larson [eds.] 2008, if to mention but three representative books dealing with this topic): their intricate language, their polymetry and stanza forms, their peculiar concept of honour and monarchy, etc. Among these, one of the major aspects that has proved thorny when transferring comedias for today's English-speaking audiences is their attitude towards women, their sexuality and the restrictive role damas and their (female) servants habitually play in the action (if compared to their male counterparts).

On the other hand, and as suggested above, the current awareness of Spanish Golden-Age plays has urged the publication and mounting of stageable versions of the teatro aureo both in England and North America. This growing trend seems to be parallel to the strong accent that, in the last years, translation has received on a multitude of new 'postmodern' perspectives

1. The contemporary success of our comedia in the English-speaking world is only comparable in History to the warm welcome it received in England during the Restoration period (cf. Braga Riera 2009).

2. Aaltonen (2004: 122) regrets the fact that, while English literary products have almost automatic access to other cultures, finding commissioners and publishers for translations into English can be very difficult, if not impossible. 
(deconstructive, postcolonial, feminist...). Thus, and as pointed out by Thacker (1999: 20), now the spotlight lies on religious and ethnic minorities, political and social issues, and, especially, on women and sex and their potential within performance. This point is especially true in the U.S., where "the most consistent research on Golden Age women has been carried out" (cf. Cruz 2001: 119).

In the comedias (a genre of Spanish drama with stock themes and characters, particularly nobles, with situations mostly about domestic intrigue), ladies are portrayed as property of men, as individuals being inseparable from the honour of their husbands, fathers or brothers, while offended husbands kill wives suspected of adultery. Love, or the feelings of a gentleman attempting to achieve the favours of his loved one, is a mainstay. Such a feeling is centred principally on the beau and his lady, and is their reason for living, although with certain differences imposed by the distinction between the sexes: the beau takes the initiative and courts the lady who, though she may at times adopt a role similar to that of the beau, reacts with the passivity expected in the society of the age. Within these limits, however, there is a scope for rebellion, but carried out in such a way which might turn out hard to grasp to those unfamiliar with the intricacies of the typical 'cape-and-sword' plays. As Bobes Naves puts it (2004: 747),

Las damas actúan en la forma conveniente para conseguir este fin [evitar un matrimonio impuesto], y son sujetos implacables de su función dramática, y para ello, aparte de una soltura envidiable en el mentir y en el urdir historias y disculpas, se muestran impenetrables a cualquier sentimiento que no sea el amoroso; no muestran amor filial, ni fraternal, ni amistoso, ni nada de nada: van derechas a conseguir lo que quieren, a casarse con su galán, pero sin plantear nunca por derecho sus derechos, sin reivindicar su libertad para elegir marido.

The apparent 'rebelliousness' which exists within the strict conventions of this genre is obviously more visible in some women characters than in others. This is the case, as we will see later on, of Fenisa in La traición de la amistad, or Rosaura in La vida es sueño, whose behaviour reveals itself as a more than plausible reason to explain why the translators opted for these sources in the first place. Hence, the fact that the majority of the plays translated into English boast strong female characters should not come as a surprise. This was also observed by RSC Associate Director Laurence Boswell when comparing one of Lope's plays, The Dog in the Manger, ${ }^{3}$ with Shakespeare's total output:

3. This play, translated by David Johnston, was one of the four productions which made up the Spanish Golden Age Season in the summer 2004. 
Certainly I'm very aware that in the Shakespearean oeuvre, although it is clear that there are some good female roles, most of the big ones, and most of the best roles, are for men. Yes, you've got Viola, and you've got Olivia, you've got Rosalind, but where's the female role to compare with Hamlet? Where's the female role to compare with Othello? Or Macbeth? Or Coriolanus? Or Timon? All the great roles are male roles. And in The Dog in the Manger we've got a fantastic one. (Boswell in Mountjoy 2005: 174)

Analogous views are expressed by the translators included in this analysis (see point 3 below). For example Tanya Ronder, in the introduction to her Peribanez, affirms that Lope's women are "a bonus", in the sense that "they are as rounded as his men [...], vivid and believable creatures, often embodying a force both natural and vivid" (p. 5). In other cases, such as La traición en la amistad, the selection of María de Zayas as a playwright for study and translation may well be a consequence, as pointed out by Mujica (1999: 404), of the plethora of investigations of women's writing in the Early Modern period, which has obviously had an impact on the Spanish classics, with scholars - translators included- paying "increased attention to representations of women in plays by both male and female authors" (ibid.: 405). ${ }^{4}$

This article attempts to go in accordance with recent studies in the field of drama translation and look into the way some of these classical plays have been rendered for contemporary British and American stages, with attention being paid to aspects in which women's roles are particularly at play. The study tries to bring to light how enhancement and downplay strategies are resorted to as recurrent tools in the process of accommodating the resulting work both to the recipient culture and to the audience's expectations. ${ }^{5}$

\section{Aim}

Zuber-Skerritt, a pioneer in Drama Translation Studies, stated clearly that "drama translation must be concerned both with the translated text (as the basis for the stage production) and the individual theatrical performances" (1984: 9). This double nature of the theatre text (as written and performed) is the reason why this analysis, far from being exclusively text-focused, also takes into account the "performative contexts" of drama (cf. Thacker 2004a: 143). Consequently, final decisions adopted by adaptors, directors or even- actors are also incorporated and included as an integrating part of the

4. In recent years this work has awoken the interest of many scholars and academics, as proved by the extensive existing bibliography on it and its author.

5. It is then that the recipient of the original text articulates the result in a new text (oral, in this case), thus provoking what Doležel calls "literary transduction" (1990: 168). 
whole process; in other words, the various signs that imply texts interpreted as theatre (verbal, paralinguistic, proxemic, kinesic, visual and acoustic) will be taken into consideration, these marking the translation strategies and reception (cf. Mateo 2002: 47). The influence of extralinguistic factors is accentuated even more in the case of the classical texts since, due to their particular nature, they are always open to multiple readings and interpretations. As a result, the possibilities offered by the translated text are so many as to inspire different productions of the same play script (this being the case of Friendship Betrayed, Life is a Dream or Sueño in our corpus).

In the following lines, an attempt will be made to throw some light into the way women's roles, as present in Golden Age drama plays, are conveyed in the target texts. To this aim, a coherent selection of originals and translations reveals itself necessary in order for definite conclusions to be drawn. Hence, a corpus made up of six Spanish (source) plays and ten performance-oriented (target) translations has been chosen as a means of exemplification. The

\begin{tabular}{|c|c|c|c|c|}
\hline Year & TRANSLATOR & TRANSLATED PLAY & $\begin{array}{c}\text { SPANISH } \\
\text { DRAMATIST }\end{array}$ & SPANISH PLAY \\
\hline 1998 & \multirow[t]{2}{*}{ José Rivera } & \multirow{2}{*}{$\begin{array}{c}\text { Sueño: A Play in Three } \\
\text { Acts }\end{array}$} & \multirow[t]{2}{*}{ Calderón } & \multirow[t]{2}{*}{ La vida es sueño } \\
\hline 2000 & & & & \\
\hline 1999 & \multirow[t]{2}{*}{ John Clifford } & \multirow[t]{2}{*}{ Life is a Dream } & \multirow[t]{2}{*}{ Calderón } & \multirow[t]{2}{*}{ La vida es sueño } \\
\hline 2004 & & & & \\
\hline 1999 & $\begin{array}{c}\text { John Barton } \\
\text { Adrian Mitchell }\end{array}$ & Life is a Dream & Calderón & La vida es sueño \\
\hline 2000 & Dakin Matthews & $\begin{array}{c}\text { The Truth Can't Be } \\
\text { Trusted }\end{array}$ & Alarcón & $\begin{array}{l}\text { La verdad } \\
\text { sospechosa }\end{array}$ \\
\hline 2003 & \multirow{2}{*}{$\begin{array}{l}\text { Catherine } \\
\text { Larson }\end{array}$} & \multirow[t]{2}{*}{ Friendship Betrayed } & \multirow[t]{2}{*}{ María de Zayas } & \multirow{2}{*}{$\begin{array}{c}\text { La traición en la } \\
\text { amistad }\end{array}$} \\
\hline 2006 & & & & \\
\hline 2003 & Tanya Ronder & Peribanez & Lope de Vega & $\begin{array}{c}\text { Peribáñez y el } \\
\text { comendador de } \\
\text { Ocaña }\end{array}$ \\
\hline 2004 & Ben Gunter & $\begin{array}{l}\text { Electing a Sheriff in } \\
\text { Podunk County }\end{array}$ & Cervantes & $\begin{array}{c}\text { La elección de } \\
\text { los alcaldes de } \\
\text { Daganzo }\end{array}$ \\
\hline 2004 & Michael Kidd & $\begin{array}{c}\text { Don Juan, Ladykiller of } \\
\text { Seville }\end{array}$ & Tirso de Molina & $\begin{array}{c}\text { El burlador de } \\
\text { Sevilla }\end{array}$ \\
\hline 2006 & Dakin Matthews & $\begin{array}{c}\text { Don Juan, the Trickster of } \\
\text { Seville }\end{array}$ & Tirso de Molina & $\begin{array}{l}\text { El burlador de } \\
\text { Sevilla }\end{array}$ \\
\hline 2007 & Nilo Cruz & Life is a Dream & Calderón & La vida es sueño \\
\hline
\end{tabular}

Table 1: Selected corpus of Spanish plays and English translations performed in Britain and America (1998-2007) 
need for brevity accounts not only for the scarce number of translated plays selected, but also for the few illustrative examples of the capital translation strategies dealt with: enhancement and downplay.

\section{The corpus of study}

This study draws on examples of translated plays belonging to a specific geographical and historical period: the UK and North America between the years 1998 and 2007. The following table summarises dates, source and target plays selected for our corpus, as well as original playwrights and translators:

As indicated above, the corpus selected gathers six Spanish plays and ten translations with their corresponding performances. Special cases are those of Larson's Friendship Betrayed, Clifford's Life Is a Dream and Rivera's Sueño, in which two different mise en scènes of the same text are considered. Larson's play was first performed in El Chamizal in 2003, and was directed by David Pasto with a cast from Oklahoma City University; its second production dates back to July 2006 and it was directed by Karen Berman, of Washington Women in Theater. Hartford (Connecticut) was the city chosen for the premiere of Sueño in 1998, which was carried out by the Hartford Stage Company (http:// www.hartfordstage.org). Rivera's translation was also the text used by José Carrasquillo in his personal direction of the same play (premiered at Theatre Olney, Washington D.C.), in summer 2000. This same year Calderón's masterpiece came to life at the Edinburgh Fringe Festival thanks to Spanish director Calixto Bieito (using John Clifford's translation). The same text was used by David Pasto and Oklahoma City Theatre Company to be shown in Oklahoma 2004. ${ }^{6}$ The play had already been produced at Court Theatre, Chicago (Sept 10-Oct 10, 1999), with the direction of JoAnne Akalaitis, this time using John Barton and Adrian Mitchell's 1990 adaptation. ${ }^{7}$ Kidd's The Ladykiller of Seville was premiered in Toronto, running from 23 September to 10 October 2004 (PLS Productions) under the direction of Julie Florio. Dakin Matthews' translation of El burlador de Sevilla was first performed in North Hollywood with the direction of Anne McNaughton, who also mounted The Truth Can't be Trusted in February 2000 with the Antaeus Company (http:// www.antaeus.org), again in North Hollywood. For its part, Ronder's Peribanez

6. Play's run: 16 April-2 May.

7. This text would also be seen in an off Broadway theatre in New York in 2001. However, the Chicago production is especially relevant since it "awakened strong community interest in the Spanish comedia" (cf. Cruz 2001: 9). 
was first staged on May 12003 at the Young Vic, London. ${ }^{8}$ The South Coast Repertory presented Life's a Dream in Costa Mesa, California, on Feb 9, 2007. Translated and adapted by Nilo Cruz, and directed by Kate Whoriskey, this is one of the latest American versions of Calderón's masterpiece (http://www. variety. com/review/VE1117932854.html? categoryid=33\&cs=1). Finally Ben Gunter, on the basis of previous translations (Edwin Honig's and others), presented his Electing a Sheriff in Podunk County in Quincy (North Florida), in 2004 as a part of his Cervantes on Stage Project.

The target plays, which are chronologically ordered in Table 1 according to the year in which they were first performed, belong to an epoch (last years of the twentieth century and first decade of the current one) in which Spanish Golden Age classics are witnessing, as already said, an unprecedented flourishing. Besides, the original playwrights of our corpus are outstanding figures in the history of drama in Spain, above all Calderón de la Barca (indeed La vida es sueño has historically been the Spanish classical play with the highest number of English translations). ${ }^{9}$ Also incorporated is one of the entremeses (one-act interludes) by Miguel de Cervantes: although formally different from the rest of the plays, as it is not strictly a comedia in format or tone, the reputation of its author deserves its inclusion in the corpus. The target plays are equally interesting: we count on different translations of the same work (this being the case of La vida es sueño and El burlador de Sevilla), or various mise en scènes of one single rendering, as in Friendship Betrayed, Sueño or Clifford's Life is a Dream. Again, Gunter's adaptation needs to be mentioned, since he defends relocation as the best way "to inspire more stageable translations of Golden Age plays" (2008: 108).

Apart from these reasons, play choice relies on other grounds too, as the women depicted in the source texts are, within the expected limits, frequently rebellious, energetic and courageous. In Zayas, female characters initiate dramatic action and are responsible for its outcomes, with fathers and brothers conspicuously absent and the ambiguous character of Fenisa wishing to have a good time and so rebel against a repressive patriarchal society (cf. Mujica

8. This play spread even beyond the shores of the British Isles and North America, as it was staged by Company B in Sydney (2006). On this occasion the director was Neil Armfield, and it received excellent reviews.

9. In fact, and just in the last two decades, at least fifteen different translations of the classic have seen the light, these being carried out by Mitchell (1990), Edwards (1991), Clifford (1998), Rivera (1999), Orti (2000), Williamson (2002), Cavander (2002), Birch \& Trend (2002), Appelbaum (2002), Davis (2003), Kidd (2004), Ness (2004), Racz (2006), Cruz (2008) and Edmundson (2009). 
2008: 242). In fact Fenisa, as a classic example of mujer varonil, is more interesting and expressive than those typical of many other comedia texts. For her part, Calderón's Rosaura is a complex, contradictory, determined woman in pursuit of both the man who affronted her and her identity after being abandoned by her father, while ready to die or to trap the person responsible of her dishonour. She is also "a confused woman", as defined by Barton and Mitchell in the list of characters to their Life is a Dream (1999: 7). Lope's Casilda is fullblooded, strong, hot-tempered and canny. Women in El burlador de Sevilla are conflict-provoking, as proved by the acts of superficial Isabela, extremely selfish Tibea and the not-so-virtuous duchess. Finally, in Cervantes' interlude the original all-men cast poses interesting questions about the way women are made present in the hands of Ben Hunter.

\section{Enhancement and downplay as translation strategies}

In the following lines, attention will be drawn to the representation of women, and hence their reactions to love and sex (as constrained by the omnipresent concept of honour), in the rendering of Spanish classical plays for the eyes of English-speaking contemporary audiences. Within the plethora of mechanisms used by the translators in this arduous task, two interesting strategies stand out: on the one hand, enhancement, that is, women's actions are intensified or increased in quality, value or power; on the other, though to a lesser extent, downplay strategies are also noticed, in the sense that the importance of women's conflicts is smoothed or minimized. What is more, sometimes acts, words or situations in which women are involved are made light of to the extent that they are even omitted or substituted by others which might suit the translators' purposes better.

\subsection{Enhancement mechanisms}

Some target texts tend to depict women with a character that is distinct from that displayed in the source plays. This can be seen not only in the stronger emphasis they habitually receive in the translations, but also in their attitudes to sex and in the linguistic register they boast, which more often than not departs dramatically from the decorum expected for the ladies — or even their servants-in the genre.

\subsubsection{Women's prominent role}

Particularly striking in some of the English texts is the fact that women's attitude not only becomes more open and liberal if compared to the originals, 
but also acquires a higher prominence, especially when characters or scenes do not imitate the sources so closely. In Sueño, for example, Rivera places Rosaura in the middle of the action, in such a way that her personal story is on a par with that of Segismundo himself. Her special status is even more visible in Carrasquillo's direction of the play: curiously enough, here Rosaura's intrepidness and thirst for revenge pass unnoticed; she is no longer a beautiful and passionate lady looking for justice, but a big, unrefined and masculine woman who distances herself from the conventional notion of beauty. According to the director, the reason for this transformation is that "Rosaura's beauty comes from the inside" (cf. Mujica 2003: 336, my translation). This emphasis on women's personality can also be noticed in the other woman character of the translated play, Estrella, who claims that Astolfo's right to govern "rests on the accidental fact that [he was] born with a penis" (p. 25).

Women's active role in the translations is evident to the extent that in some cases new female characters are created when there is no counterpart in the source texts. Thus, while madres are totally absent in Spanish comedias, Segismundo's mother is given in Sueño some presence on stage (to be precise at the moment she gives birth to her son). In Gunter's Electing a Sheriff in Podunk County, the two anonymous gypsy women in the original acquire in English a more active role as two scrub-women, Mexican migrants: Miguelita Saavedra and Sanchita Quixote. What is more, some male roles are even replaced by others that are impersonated by females: ${ }^{10}$ Gunter transforms three of the four male candidates to become a sheriff into women: Honest Ava, Jane Colecoke and Michelle Potshot, all of them speaking or 'loaded' names, ${ }^{11}$ as it is the case in Cervantes. Even the judge (Bachiller Pesuña in the Spanish version) turns into a woman called Judge Hangman, and the same can be said for two of his assistants: Alonso Algarroba (Ms Petra Kerchuski in the American case) and Pedro Estornudo (now Ms Lonnie Snappea). This feminine presence occasionally functions as an excuse for the discussion of contemporary political women's issues which, needless to say, are absent in the seventeenth-century

10. This sort of substitutions can also be seen in other translations of Golden Age dramatic works that are not included in this study. For instance, in Nick Dear's version of Tirso's El burlador de Sevilla the clown, Catalinón, is turned into Catalina. According to Gunter, through this change the translator "succeeds in bringing four critical functions of the gracioso's role to life in contemporary English at the same time" (s.a.: 234).

11. Hermans (1988: 13) uses this term to refer to those names whose meaning denotes certain characteristics of the bearer (as against those labelled 'conventional'). 
interlude. ${ }^{12} \mathrm{~A}$ revealing example is the following conversation between Col. Cornpone, of the Republican Party, and newly feminist Snappea:

Snappea: I'm here to tell you that all women are created equal, and have been endowed by their Creator with certain inalienable rights, among which are life, liberty, and the pursuit of happiness.

Cornpone: HA! That's a rich one! Ms. Snappea loves to pick on me when I bobble a few big words in public. Now she's standing right here, telling the press that God created women's endowments so aliens could take liberties with 'em!

Also relevant are the undertones in Cornpone's presentation of his candidate, Michelle Potshot (bleeps are inserted by the translator to substitute swearwords):

Cornpone: You think sipping Coke is something? Bleepity bleep, woman take a good look at my Republican Party nominee. Michelle Potshot is a founding member of the National Rifle Association. She's a bleepity bleepbleep one-woman army of one!

Equally Lauro is eliminated entirely in Friendship Betrayed (2003), while the remaining male roles in Zayas's play are characterized much weaker than the females (Gerardo, for instance, is portrayed as feeble and effeminate). Additionally, extralinguistic factors can also favour the prominence of female characters in the translated texts. In the performance of Clifford's Life's a Dream... (2004) Pasto made the interesting choice of casting a woman (Ariel Allison) in the role of Clarín. Apparently, the actress touchingly brought out the vulnerability beneath Clarín's bravado (cf. Weimer 2005: 229), putting the character of the gracioso to a different perspective. Clothes can also serve a similar purpose, as we will see later on.

Finally, the language these women use and their attitudes towards sex do nothing but reaffirm their higher status in the target texts.

\subsubsection{Sex}

Translator William I. Oliver (1991: 156-157) has observed how, in the translation process, sometimes certain themes present in the source classical plays may be disguised, if not alleviated, by technical distractions. One of these distractions is precisely explicit sex and nudity, two resources which are frowned upon by Oliver himself on the basis that "sex and sensuality should serve the

12. This feminist stance is also appreciated in other stagings that lie outside the aims of this study, as a 2007 production of Life is a Dream at the New York Flux Theatre Ensemble, using Clifford's translation (cf. Avellone 2007). 
situation and should serve the play's action" (1991: 160). Despite controversy, it is a fact that many times translators and directors attempt to entertain our eye by making women's situations greater in intensity using, precisely, explicit sex and (partial) nudity. In Friendship Betrayed (2006), Fenisa is dressed with Madonna-like bustiers and makes suggestive facial expressions and body movements to state clear she sleeps with the men she seduces; this is made evident in sentences such as the following, uttered with the accompaniment of insinuating body language.

FENISA: ¡Jesús, Lucía! Pues, ¿a Lauro niegas la entrada? Pues, la tiene ya en mi alma.

La traición en la amistad, p. 168
FENISA: Goodness, Lucia! You have not let Lauro in? Why, I have already let him enter my soul.

Friendship Betrayed, p. 169

This open attitude towards men displayed by Spanish Fenisa is anticipated at the beginning of the play in a phrase that, though too liberal for the standards of the genre, is surpassed in tone by the boldness of the English words:

FENISA: No digas que a nadie estoy obligada sino a mi gusto

La traición en la amistad, p. 53
FENISA: I am not obligated to anyone or anything except my own pleasure.

Friendship Betrayed, p. 43

The connotations of "pleasure" imply more sensual gratification than those contained in the Spanish word "gusto". Besides, American Fenisa does not hide the fact that she actually has sex with her men, whereas the original keeps her virginity intact. In order to find a contemporary American equivalent of this aristocratic, 'empty-headed' woman, the solution director Berman (2006) comes up with is to reconstruct Fenisa as a spoiled celebrity, similar to Britney Spears or Paris Hilton: long, blonde, tied-back hair, svelte figure and spectacular legginess, with pieces of underwear when they are at home (the domain of women), whereas in contrast men wear suits (cf. Mujica 2008: 248)..$^{13}$

Fenisa's liberal attitude in the target play somehow reminds us of her male counterpart in literature, Don Juan. In fact, in the first lines of El burlador de Sevilla Isabela shows Don Juan out after a night of apparent courtship. Again, translations go a step further, and in the opening scene of The Ladykiller...

13. This 'openness' is even extended to the portrayal of men in the cast. For instance one of the gentlemen, León, is transformed into a bisexual who repeatedly comes on to Liseo, the other beau. 
Kidd situates the lady gasping and giggling with Don Juan under her skirt. Needless to say such references are totally absent in the original text. For her part, JoAnne Akalaitis, when directing Life is a Dream (1999), emphasizes the scene when Segismundo wakes up in palace for the first time and feels captivated by Rosaura's beauty. The director shows a fierce brutality, presenting Rosaura lying on the floor and Segismundo on top with an aim to rape her, thus accentuating the emotional impact of the scene. Again the feminist stance of the director reveals itself as a non-verbal factor that acts upon drama translation. In this same scene she even decided to change in the lines the word "loved" (as appearing in both original and translated dialogues) for "wanted", since, according to her, "Rape is not love. Rape is never love" (cf. Wilks 2001: 72).

Scenes of explicit sex abound in other target plays, too. In Peribanez, the translator adds a complete new scene at the end of act three in which the woman protagonist, Casilda, slowly "begins to undress in front of him [her husband]" (p. 82). Also the director plays up the physical aspect of rape, making Casilda a veritable victim of sexual abuse. This is supported in the translation (though not in the source play) by Peribanez's actual words, as he specifically says that "she was half naked, her clothes were on the floor, she was screaming" (p. 80). The translator's added stage directions undoubtedly contribute to this interpretation throughout the work, too: "The commander reaches out and tries to hold on to Casilda" (p. 14), "She manages to prise his hands off her" (p. 14), "The commander grabs hold of Casilda and roughly gets most of her clothes off and some of his own so he can put himself in her" (p. 73), etc. In Life is a Dream, Nilo Cruz lets Segismundo kiss Estrella by means of a stage note ("He begins to kiss her hand and arm", p. 30). More powerful is the scene in Sueño in which Calderón's hero attempts to rape Rosaura, because the act is simulated by means of mimics and acrobatics which, in Mujica's view, "intensifies the impact of Segismundo's acts, since suggestive ballet movements act upon the audience's imagination" (2003: 337, my translation). In the hands of Barton and Mitchell, this scene is also more obvious: "He throws her on the bed and starts to tear her clothes off" (p. 58).

In fact kissing scenes, though totally absent from the originals, are not infrequent in the target texts. Again in Peribanez, the protagonist asks his wife to kiss him (p. 16), and later on a stage direction announces that "he kisses her fully" (p. 18) and "brings Casilda to him for a kiss" (p. 24). Besides, examples of the women's daring attitude towards sexuality are constant throughout the play: 
INÉS: ¿Quiérete bien tu velado? CASILDA: ¿Tan presto temes mudanza?

[...] aún comemos los picos de las roscas de la boda.
INÉS: Does he still love you?

CAS: What do you expect? We are still eating the wedding cake.

COS: Does he do a lot of fantastic

things to you?

INÉS: Costanza!

Peribanez, p. 22

Peribáñez... p. 89

Here sex does become verbal in a new line without correspondence in Lope. Similar is the case we find later on when, talking to her cousins about her new marital life, Casilda proudly refers to the time when she goes to bed, "where I wish we could stay forever" (p. 23); even Leonardo dares to promise to his commander that Casilda "will open for you like an oyster" (p. 49). Also along this line goes the following extract from Sueño, which belongs to the scene where a disguised Rosaura reveals her true identity to Clotaldo: ${ }^{14}$

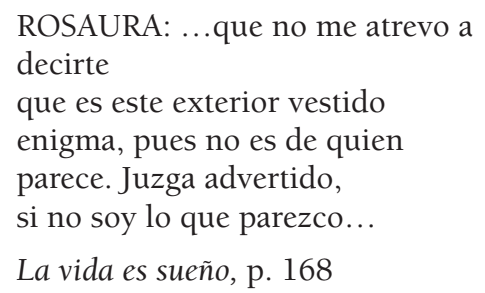

La vida es sueño, p. 168

\begin{abstract}
ROSAURA: Look in my eyes, sir. Run your hand along the soft curves of my face. Listen to the strange pitch of my voice. Though I possess the swords and daggers of a man... I lack his "ultimate weapon".
\end{abstract}

Sueño, p. 31

With her words, Rosaura states something which reveals the phallic connotations of the sword, while also altering the register and language expected from a woman of her social position.

\subsubsection{Language and register}

Decorum, as a major principle in the Spanish comedia, expects characters to conform actions and language to their assigned sex and social status. However, the women's daring attitude in the target texts (as shown in points 4.1.1 and 4.1.2) can obviously have some consequences in the sort of idiom they employ. This makes itself evident mainly in two aspects: love talk and terms of abuse.

In the process of linguistic translation for the stage when a source text is archaic or classical, there is a tendency, as Fischer has noted, to alleviate the

14. Although less evidently, Barton and Mitchell's translation also accentuates Rosaura's feminine condition at this point of the action: "I am not what I seem, / this is show, disguise, a costume. / My name is Rosaura [Lets down her hair]". 
archaism and remoteness of the language that can create problems for today's audiences, and so "the contemporaneity of the target idiom frequently works to bridge the gap between past text and (post)modern context" (2007: 36). As a matter of fact, this applies not only to a linguistic transfer between cultures, but also to the transformation process undergone by a play text to create a different version in the same original language..$^{15}$ However, in the particular case of Golden Age theatre language may enter in contradiction with the decorum expected, especially in high-rank characters. Notice, for instance, Casilda's words when addressing her maid: "What are you, mistress of a whore-house?" (Peribanez, p. 72), when a simple 'alcahueta' (go-between) is read in the Spanish dialogue. Besides, it is precisely in this translation that bride and groom engage openly in love talk, as proved by the following words — not present in Lope- and uttered by Peribanez when addressing his wife: "Ask me anything you like. I want to sink my troubles in you, my lovely Casilda" (p. 16). As it can be appreciated, the sexual innuendo is not obscure in the mouth of the protagonist. His wife, Casilda, is not far behind in this respect; this is openly seen in her body language when she 'spells' the rules of a good husband, which provokes in turn her husband's interested comment and her further insinuating reply (both absent in Lope's text):

CASILDA: Por la V verdad tratarme;

Por la X con abiertos

Brazos imitarla así [abrázale]

Peribáñez..., p. 80
CASILDA: Because $\mathrm{X}$ is for this [she opens wide her arms and legs] [...] PERIBANEZ: But tell me again, what was in your spelling book for ' $\mathrm{X}$ '...? CASILDA: Um...

Peribanez, pp. 17-18

As for terms of abuse, Sueño contains a whole panoply of examples. The irreverent idioms and ideological amplifications of Rosaura's opening lines addressing her horse are a valid sample:

15. In this respect, Brioso (2007: 11) uses the Spanish negative words manipulación y distorsión to refer to a common practice in contemporary Spain when staging seventeenth-century classical drama. Some English translators are also against any kind or modernization or adaptation of the dramatic texts, as is the case of Robert Lauer, who finds it "an insult to any audience and a condescending display of arrogance" (2008: 205). See also Bayliss (2006) and his concept of "textual authenticity". 
ROSAURA: Hipogrifo violento que corriste parejas con el viento, ¿dónde, rayo sin llama, pájaro sin matiz, pez sin escama...?

La vida es sueño, pp. 94-95
ROSAURA: Violent, mixed-up horse. Unnaturally stupid mammal! Instinctchallenged freak! [...] You are a fart without smell! A religion without God!

Sueño, p. 13

Later on, Estrella calls Astolfo "a shitty boy friend". Also in this play, Astolfo refers to goddess Aphrodite as a "maggot poop", a commentary to which Estrella responds: "Cool off, duke. It's bullshit" (p. 24). Needless to say such open insults do not fit within the Baroque poetry and the mythological allusions one should expect to find in Calderón's ladies. This lack of politesse can even be observed in women's allusions to respected figures such as the father, as does Rosaura in Barton and Mitchell's text:

CLOTALDO: ... mas cuando fuera tu padre.

ROSAURA: Cuando tú mi padre fueras

sufriera esa injuria yo.

La vida es sueño, p. 283
CLOTALDO: Were I your father... ROSAURA: I would spit at you.

Life is a Dream, p. 97

Nilo Cruz also uses this technique in his adaptation of the Calderonian play: ¡Válgate Dios, Rosaura! (p. 240) > "Damn you, Rosaura!” (p. 41), as also do Barton and Mitchell: "¿Yo tuya, villano? ¡Mientes! (p. 237) > "I am not [yours], you lie. / You bully, you liar" (p. 68). The same is true in the rendering of many terms of abuse scattered throughout women's lines in other source texts: Jacinta's “¡Válgame Dios!” and “¡embustero!” in La verdad sospechosa turn into drastic "Damn!" (p. 33) and "That cheat! That fraud! That liar" (p. 37), respectively. Also illustrative is the celebrated fight between Fenisa and Belisa in Friendship Betrayed, where language becomes less contentious when converted into English:

BELISA: ¡Mientes, villana grosera! FENISA: ¡Agora verás quién soy! [las dos pelean]

La traición en la amistad, p. 188
BELISA: You are lying, you disgusting low-class villain!

FENISA: You will see what I am made of now! [The two women fight]

Friendship Betrayed, p. 189

\subsection{Downplay mechanisms}

On occasions, the translator attempts to minimize the impact of certain aspects in the source plays that specifically concern women. This is particularly 
visible when contemporary political correctness is at play, or in scenes in which the pervasive Spanish code of honour makes its unavoidable appearance, to the translators' dismay.

\subsubsection{Political correctness}

Translating Buero Vallejo's Misión al pueblo desierto (1999), Patricia O'Connor admittedly faced some problems when rendering the following phrase into English: "Pero mi padre no podía ser mi marido". Given our current awareness of sexual abuse within families, and in order to avoid alarm bells setting off, she discarded "But I couldn't marry my father" and opted for "I wanted a man like my father, but never found one" (2006: 10-11).

This sort of decisions also applies to contemporary translations of the Spanish classics. As noticed by Christiane Nord, "modern translations of ancient texts may have to take norms or conventions of 'political correctness' into account that prevail in the target culture at the moment of translation" (2002: 37). The application of political correctness is perfectly visible in some circumstances in which feminine issues are involved, thus contributing to downplay women's roles. In this respect, a good example is the hair-pulling cat-fight scene between Belisa and Fenisa in La traición...: In Friendship Betrayed (2003) this fight is substituted by sword brandishing. Allegedly, the original scene might convey negative impressions to audiences today, so by providing women with swords they are raised to a status equal to men, thus "challenging female conventions" (cf. Voros 2008: 238). This elimination also avoids "the problematic nature of showing women fighting on the stage, for even by today's standards, female body action is arguably more limited than that of males" (ibid.: 237). Unfortunately, the actresses' lack of skill in wielding the swords weakened the climax of the play (cf. López-Mayhew 2004: 269). Such a decision consequently brought about the suppression of some lines, such as Leon's comment on the fight with these words: "They were pulling each other's manes out" (p. 189). As for the translator, she inexplicably omits part of a stage note in which indications are made for Felisa to strike servant Leon, breaking him some teeth. The tooth problem is absent in the target play:

[Fenisa golpea a León, y le rompe unas muelas]

La traición en la amistad, p.112
[Fenisa strikes León]

Friendship Betrayed, p. 113 
Political correctness might also be behind some other decisions taken which affect women tangentially. Cruz and director Kate Whoriskey, for example, changed their original reading of Life is a Dream, which was done with an allHispanic cast, to diversify it for the full staging of the adaptation (http://www. epinions.com/content_321014894212). Also Bieito chose a racially mixed ensemble in his production of Life's a Dream, which additionally counted on Spanish onstage musicians (cf. Brantley: 1999).

\subsubsection{Vagueness}

In order to be loyal toward the original playwright a translator may have to stick to a particular interpretation where the source text seems to be too 'vague' or conveys ideas which might be difficult to understand by the receiving culture:

CASILDA: No conviene a tu decoro

El día que te has casado,

Ni que un rezién desposado

Se ponga en cuernos de un toro.

PERIBÁÑEZ: Si refranes considero,

Dos me dan gran pesadumbre:

Que a la cárcel, ni aún por lumbre

Y de cuernos, ni aún tintero.

Peribáñez... p. 68
CASILDA: Just the thing for a newly married man - to impale yourself on a mad bull's horns...

PERIBANEZ: There are better things to do...

Peribanez, p. 11

With the word "cuernos" Casilda and Peribáñez not only refer to the horns of the bull or those used to make inkwells, but to the dangers of cuernos as a synonym of being cuckolded, an implication which vanishes in the English case. In this translation, too, the actual words with which Casilda approves of her cousin's murder by Pedro are omitted, as considered a harshness the British modern audience might struggle with. This had the play ending in a way that may be out of key to the specialist (cf. Thacker 2004b: 265).

Other times, the open interpretation of a particular scene can lead to perplexing solutions, as that adopted by JoAnne Akalaitis in her Life is a Dream: Rosaura begins the show galloping around the stage on a hobbyhorse (as indicated in a stage note in Barton and Mitchell's translation), dressed in the black velvet and gold-trimmed attire of a virile young matador (cf. Bechtel 2000: 406). Both this outfit and the fact that her servant Clarion follows her in a shiny golden polyester suit and platform shoes do not definitely contribute to mark the graveness of the moment. It is precisely in the translation used for this staging where we find another example, in this case connected to a 
particular interpretation of Hispanic honor: instead of emphasizing Rosaura's quest to restore her honour or her influence in Segismundo's transformation, the translator chose to stress her confusing relationship with Astolfo, thus failing "to capture the character's complexity" (cf. Wilks 2001: 67). Honour, hence, emerges as a harsh theme to deal with in current productions of Golden Age plays.

\subsubsection{Women's honour}

BELISA: Don Juan, ninguna mujer, si se tiene por discreta, pone en opinión su honor, siendo joya que se quiebra.

La traición en la amistad, p.134
BELISA: Don Juan, no woman, if she considers herself prudent, puts her honour up for public discussion, since it is a precious jewel, easily broken.

Friendship Betrayed, p. 135

With these words, Belisa defined one of the driving forces of the genre, that is, a notion of honour which affects women directly and is always present in the source texts with the meaning of honra, or chastity. As we can see in the example the reference to honour has been maintained, as is also the case in many instances of our corpus. However, on many occasions such references are substituted or eliminated altogether, their deletion mostly responding to a desire to alleviate the oft-repeated motif. As Paun de García \& Larson state (2008: 3), the pervasive presence of the theme of honour is usually irrelevant, or even repugnant, for current adaptors of Spanish plays. This antipathy was clearly expressed by JoAnne Akalaitis in directing Calderón's La vida es sueño. According to her, this strict code was the most problematic thing she came across in her activity, as it "clashes with contemporary feminist vision of women's honour" (cf. Schizzano 2003: 421). Hence, and as part of a feminist agenda, she refused to follow Segismundo to resist his attraction for Rosaura, inevitably changing the spirit of the original. ${ }^{16}$ The same can be said about the typical forced marriages demanded by this strict code, which brings about situations that Anglo-Saxon audiences may find hard to grasp. Hence, José Rivera added a totally new scene to Sueño and, in a typical Broadway happyend, marries Rosaura not to Astolfo (as expected in accordance with the original and the rules of honour) but to Segimsundo. ${ }^{17}$ Actually, Rosaura's father

16. According to Thacker (2004: 151), "this left the cast and presumably the audience scratching their heads".

17. Interestingly enough, identical matching occurs in Laird Williamson's translation of the same play (Denver 1998), which is not included here. Allegedly, the complexity of 
wanted her "casada, noble y honrada" (p. 322); In Cruz's version, Clotaldo just hopes she gets "properly married" (p. 63).

The following excerpt taken from La verdad sospechosa vividly illustrates the lighter effect this particular honour requisite has in the target text:

BELTRÁN: ¡Vive Dios, si no recibes a Lucrecia por esposa, te he de quitar la vida!

La verdad sospechosa, p. 156
BELTRÁN: By God, if you don't marry that Lucrecia, you'll lose a lot more Than that, my boy! I'll strike you dead! The Truth Can't Be Trusted, p. 84

There is no doubt that the choice of the expression "my boy" by the infuriated father when addressing the husband-to-be alleviates the severe atmosphere this type of situation requires.

Other times, the translator opts for the replacement of references to women's honour with others which might be easier to understand or accept by potential target audiences. In Peribañez..., the protagonist laments the fact that his honour, now central theme of a popular song, is in question. Its English equivalent prefers just to focus on the pain:

PERIBÁÑEZ: Pena tengo con razón, porque honor que anda en canciones tiene dudosa opinión.

Peribáñez..., p. 146
PERIBANEZ: But still they are singing about her. Us. And it shakes my sickened soul!

Peribanez, p. 52

These substitutions can sometimes be compensated with other expressions which have an explanatory function: In El burlador de Sevilla, the king discovers the presence of Don Juan in Isabela's house. The lady knows about the consequences this act conveys, which are explicitly clarified in the English version:

¡Ay perdido honor!

El burlador de Sevilla, p. 69
I'm ruined, I'll die!

Don Juan, the Trickster of Seville, p. 5

A similar case is that indicated in Tisbea's remark, later on in the play:

¡Dejas a una mujer deshonrada!

El burlador de Sevilla, p. 110
To ruin a girl like me!

Don Juan, the Trickster of Seville, p. 34

the rules of honour made these changes necessary if to guarantee the comprehension/ acceptance on the part of the (American) audiences. 
Finally, honour can be minimised to the point of being mocked at. In the following lines (Act I of Clifford's Life is a Dream) Rosaura states clear the purpose of her arrival in Poland: "To find my lost father / and win back my honour" (p. 10). Clarion's response (Mitchell and Barton's own creation) does not take the aim of his 'master' seriously: "I rose up one morning / and hurried to the fair, / for I had heard the rumour / that the folk sold honour there" (p. 10). The mocking effect is accentuated by the fact that the servant actually sings these words.

\section{Conclusions}

In the last twenty years, Spanish Golden Age dramatists have experienced a huge revival in the Anglo-Saxon theatre world, with an ever-growing number of English translations meant for the stage. However, and despite this increasing interest, it is a fact that British and American spectators, actors and directors are largely ignorant of Hispanic seventeenth-century drama. Some of the intrinsic problems derived from their rendering into another language and culture could explain the paucity of comedias in translation, those being mainly the intricate polymetry and a strict code of honour that determines women's behaviour, among others.

Throughout these pages we have seen how some women's roles in their different manifestations (verbal and stage) are transposed from the Spanish classical books to present-day American and British stages. Far from intending to be a prescriptive study of what the playwrights-adaptors should have done with the Spanish originals, this analysis has attempted to describe the way some women's issues present in the source texts are actually tackled, with varying results. In this transfer, and following functional notions of translation, the target-culture's norms are given a priority, with frequent adjustments made to the resulting play in order to adapt it to the recipient's expectationsgenre conventions included - while trying to gain acceptability.

Thus, and taking a corpus of ten translated works staged during the period 1998-2007 as a means of exemplification, two different strategies are object of study, i.e. enhancement and downplay, the latter being less recurrent. By means of enhancement translators attempt to alleviate the rigidity of women's position by boosting different aspects of their personality. The resulting characters are, then, more strong and open, and their attitude to sex at times radically departs from that expected according to the conventions of Siglo de Oro plays. What is more, their language becomes more daring, drawing it closer to contemporary notions of speech rather than to the decorum required in the genre. Hence, sex talk, insults and other terms of abuse are heard more often 
in the voices of damas and their servants. On the other hand, downplay comes into force when some manifestations in the source texts involving women need to be 'softened', and for the most varied reasons, as the need to be politically correct or vague, when not to let go a particular concept of honour which leaves little space for women to act freely.

The reasons that have impelled the translators (and directors) concerned to choose some of the above-mentioned strategies, and not others equally valid, can be very complex and not always easy to identify. What seems to be true is that they act in accordance with their perspectives on contemporary drama translation practice, and to a certain extent they become 'creators' who alter the source texts for their particular needs or those of the potential spectators. In this way, the resulting plays become more 'British' or 'American'.

The present article intends to constitute a starting point for the study of feminine roles in Spanish classical theatre when transferred to present-day UK and America. Further comparative analyses of wider corpora will undoubtedly draw more significant conclusions about the way this motif, or other, is rendered for English-speaking theatregoers. Yet to be discussed is whether these audiences witness authentic Siglo de Oro women when they attend the performances, or rather translation is providing them with something else.

\section{References}

Play editions

Calderón de la Barca, Pedro. (1994) La vida es sueño. Ed. by José M. Ruano de la Haza. Madrid: Castalia.

Calderón de la BArCA, Pedro. (1990) Life is a Dream. Translated by Adrian Mitchell and John Barton. Woodstock: Dramatic Publishing.

Calderón de la Barca, Pedro. (1999) Sueño: A Play in Three Acts. Translated by José Rivera. Woodstock: Dramatic Publishing.

Calderón de la Barca, Pedro. (2007) Life is a Dream. Translated by John Clifford. London: Nick Hern Books.

Calderón de la BarCa, Pedro. (2008) Life is a Dream. Translated by Nilo Cruz. New York: Dramatists Play Service.

Cervantes, Miguel de. (1997) "La elección de los alcaldes de Daganzo". In: Entremeses. Ed. by Javier Huerta Calvo. Madrid: Edaf.

Cervantes, Miguel de. (2007) Electing a Sheriff in Podunk County, Florida. Translated by Ben Gunter. Internet edition at http://spanish-golden-age-plays. wikispaces.com/Cervantes +on+Stage+Project+(Ben+Gunter).

Lope De VegA, Félix. (1987) Peribáñez y el comendador de Ocaña. Ed. by Juan María Marín. Madrid: Cátedra. 
Lope de VegA, Félix. (2003) Peribanez. Translated by Tanya Ronder. London: Nick Hern Books.

MolinA, Tirso de. (1999) El burlador de Sevilla. Ed. by Héctor Brioso. Madrid: Alianza Editorial.

Molina, Tirso de. (2004) Don Juan, Ladykiller of Seville. Translated by Michael Kidd. Unpublished.

Molina, Tirso de. (2006) Don Juan, the Trickster of Seville. Translated by Dakin Matthews. North Hollywood: Andak Theatrical Services.

Ruiz de Alarcón, Juan. (1990) La verdad sospechosa. Ed. by Juan María Marín Martínez. Madrid: Espasa Calpe.

Ruiz De Alarcón, Juan. (2000) The Truth Can't Be Trusted. Translated by Dakin Matthews. North Hollywood: Andak Theatrical Services.

ZAYAS, María de. (1994) La traición en la amistad. Ed. by Felicidad González \& Fernando Doménech. Madrid: Asociación de directores de escena de España. ZAYAS, María de. (1999) Friendship Betrayed. Translated by Catherine Larson. Lewisburg: Bucknell University Press.

\section{General}

AALtONEN, Sirkku. (2004) "Olga's Eightsome Reel in Edinburgh: A Case Study of Finnish Drama in English Translation". In: Drama Translation and Theatre Practice. Frankfurt am Main: Peter Lang. pp. 121-135.

Avellone, Jesica. (2007) "Life is a Dream". Mytheatre.com Review, June 8. http:// www.nytheatre.com/nytheatre/showrevprint.php?t=life5350. (Accessed in June 2010)

BAYLISS, Robert. (2006) "Ancients, moderns, and the authenticity issue in the comedia performance scholarship". Comedia Performance 3:1. pp. 121-145.

BECHTEL, Roger. (2000) "Review of Life is a Dream". Theater Journal 52: 3. pp. 405-407.

Bobes NAVES, Carmen. (2004) "Comedias de honor y celos". In: Largo mundo alumiado. Estudos em homenagem a Vitor Aguiar e Silva. Braga: Centro de Estudios Humanísticos, volume 2. pp. 745-750.

BoYle, Catherine \& David Johnston (eds.) (2008) The Spanish Golden Age in English: Perspectives on Performance. London: Oberon Books.

Braga RierA, Jorge. (2009) Classical Spanish Drama in Restoration English (16601700). Amsterdam \& Philadelphia: John Benjamins.

BRANTLEy, Ben. (1999) "Metaphysical Wrestling, With No Holds Barred". The New York Times, October 1999 http://theater2.nytimes.com/mem/theater/treview. html?html_title=\&tols_title=LIFE\%20IS\%20A\%20DREAM\%20(PLAY) \& byline $=$ By\%20BEN\%20BRANTLEY $\&$ pdate $=19991014 \&$ id $=1077011430574$. (Accessed in June 2010) 
BRIOSO, Héctor. (2007) "Del arte nuevo de deshacer comedias en este tiempo o la adaptación del teatro clásico a la escena actual". In: Brioso, H. \& J. V. Saval (eds.) Nuevas aportaciones a los estudios teatrales (del Siglo de Oro a nuestros días). Alcalá: Universidad. pp. 11-24.

Cruz, Anne J. (2001) "American Calderón: A Prelude." Bulletin of the Comediantes 53:1. pp. 9-13.

DoležEL, Lubomír. (1990) Occidental Poetics: Tradition and Progress. Lincoln \& London: University of Nebraska Press.

FISCHER, Susan L. (2007) “Aspectuality, Performativity and 'Foreign' Comedia: (Re)iteration of meaning for the stage". In: Boyle, C. \& D. Johnston (eds.) The Spanish Golden Age in English. London: Oberon Books. pp. 31-48.

Gunter, Ben. (2008) "Translation as relocation". In: Paun de García, Susan \& Donald R. Larson (eds.) The Comedia in English: Translation and Performance. Woodbridge: Tamesis. pp. 108-124.

GUNTER, Ben. (s.a.) Targeting re-production of the 'untranslatable': using reproduction conceptualization to transmit non-verbal performance information. Unpublished dissertation.

Hermans, Theo. (1988) "On Translating Proper Names, with reference to De Witte and Max Havelaar". In: Wintle, Michael (ed.) Modern Dutch Studies. Essays in Honour of Peter King. London: Athlone Press. pp. 11-24.

LAUER, Robert. (2008) “Anne McNaughton's Don Juan: A Rogue for All Seasons". In: Paun de García, Susan \& Donald R. Larson (eds.) The Comedia in English. Translation and Performance. Woodbridge: Tamesis Books. pp. 202-213.

LÓPEZ-MAYHEw, Barbara. (2004) "Review of Friendship Betrayed". Comedia Performance 1:1. pp. 266-273.

Mateo, Marta. (2002) "Power Relations in Drama Translation". Current Writing 14:2. pp. 45-63.

Mountjoy, Kathleen. (2005) "Interview with Laurence Boswell". Comedia Performance 2:1. pp. 171-192.

MujICA, Barbara. (1999) "Early Modern Theater: Comedia Studies at the End of the Century". Hispania 82:3. pp. 397-407.

MujicA, Barbara. (2008) "María de Zayas's Friendship Betrayed à la Hollywood: Translation, Transculturation, and Production." In: Paun de García, Susan \& Donald R. Larson (eds.) The Comedia in English. Translation and Performance. Woodbridge: Tamesis Books. pp. 240-253.

O'CONnOR, Patricia. (2006) "Translating Plays: The Juggling of Knowledge, Creativity and Public Relations". Paper read at the University of Oviedo, Spain, November 2006.

Oliver, William I. (1991) "Lope de Who? (A Director Do's, Don'ts, and Headaches)”. In: Fothergill-Payne, Louise \& Peter (eds.) Prologue to Performance: 
Spanish Classical Theater Today. Lewisburg: Bucknell University Press. pp. 153-167.

PAUn DE GARCíA, Susan \& Donald R. Larson (eds.) (2008) The Comedia in English: Translation and Performance. Woodbridge: Tamesis Books.

RuAnO DE la HazA, José María. (2005) "Spanish Classical Theory in Britain and North America”. Romance Quarterly 52:1. pp. 2-12.

SCHIZZANO MANDEL, Adrienne. (2003) "La vida es sueño: nuevas interpretaciones escénicas". In: Teatro calderoniano sobre el tablado: Calderón y su puesta en escena a través de los siglos. Stutgart: Franz Steiner. pp. 443-454.

THACKER, Jonathan. (1999) "Rethinking Golden-Age drama: The Comedia in its Contexts". Paragraph 22. pp. 14-34.

THACKER, Jonathan. (2004a) "Puedo yo con sola la vista oír leyendo: Reading, Seeing and Hearing the Comedia". Comedia Performance 1:1. pp. 143-173.

THACKER, Jonathan. (2004b) "Review of Peribáñez". Comedia Performance 1:1. pp. 260-265.

Voros, Sharon D. (2008) "Zayas's comic sense". In: Paun de García, Susan \& Donald R. Larson (eds.) The Comedia in English: Translation and Performance. Woodbridge: Tamesis. pp. 229-239.

WeImer, Christopher. (2005) "Review of Life Is a Dream". Comedia Performance 2:1. pp. 229-233.

WILKS, Kerry. (2001) "Interpreting ideas: Court Theatre's production of Life is a Dream". Bulletin of the Comediantes 53:1. pp. 57-82.

ZatLin, Phyllis. (2005) Theatrical Translation and Film Adaptation. Clevedon: Multilingual Matters.

ZubER-SKerRit, Ortrun (ed.) (1984) Page to Stage. Theatre as Translation. Amsterdam \& Atlanta: Rodopi B. V.

Web pages (by order of appearance)

http://www.hartfordstage.org

http://www.antaeus.org

http://www.variety.com/review/VE1117932854.html? categoryid=33\&cs=1

http://www.epinions.com/content_321014894212 